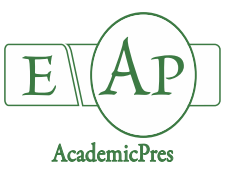

Alzahrani O et al. (2021)

Notulae Botanicae Horti Agrobotanici Cluj-Napoca

Volume 49, Issue 2, Article number 12310

DOI: $10.15835 /$ nbha 49212310

Research Article

\title{
Agronomical, physiological and molecular evaluation reveals superior salt-tolerance in bread wheat through salt-induced priming approach
}

\author{
Othman ALZAHRANI ${ }^{1,2}$, Heba ABOUSEADAA 3 , Taghreed K. \\ ABDELMONEIM ${ }^{4}$, Mohammed A. ALSHEHRI ${ }^{1,2}$, Mohamed M. EL- \\ MOGY5 ${ }^{5}$ Hossam S. EL-BELTAGI ${ }^{6,7}$, Mohamed A.M. ATIA ${ }^{4 *}$ \\ ${ }^{1}$ University of Tabuk, Faculty of Science, Biology Department, Tabuk, Saudi Arabia; o-alzahrani@ut.edu.sa \\ ${ }^{2}$ University of Tabuk, Faculty of Sciences, Genome and Biotechnology Unit, Tabuk, Saudi Arabia \\ ${ }^{3}$ Ain Shams University, Faculty of Science, Botany Department, Giza, Egypt; heba_1st@hotmail.com \\ ${ }^{4}$ Molecular Genetics and Genome Mapping Laboratory, Genome Mapping Department, Agricultural Genetic Engineering Research \\ Institute (AGERI), Agricultural Research Center (ARC), Giza, 12619, Egypt; matia@matia.org ("corresponding author); \\ taghredkhalid1997@gmail.com \\ ${ }^{5}$ Cairo University, Faculty of Agriculture, Vegetable Crops Department, 12613 Giza, Egypt; elmog@agr.cu.edu.eg \\ ${ }^{6}$ King Faisal University, Agricultural Biotechnology Department, College of Agriculture and Food Sciences, P.O. Box 420, \\ Al-Ahsa 31982, Saudi Arabia; helbeltagi@kfu.edu.sa \\ ${ }^{7}$ Cairo University, Faculty of Agriculture, Biochemistry Department, Gamma St. Giza 12613, Egypt
}

\begin{abstract}
Salt stress significantly limit wheat crop productivity worldwide. Exposure to non-lethal levels of salt stress, referred to as "salt-priming", allows plants to persist subsequent lethal conditions; the priming effect continues even after an extended salt stress-free period. This study attempted to evaluate the effectiveness of the salt-induced priming approach to cope with the toxic effects of long-term salinity stress in wheat. After 22 days of gradual salt acclamation to reach $250 \mathrm{mM} \mathrm{NaCl}$, plants were recovered for eight days and finally shocked with $250 \mathrm{mM} \mathrm{NaCl}$ (priming+shock) for 7 days. After that, physiological parameters and gene expression of six salt-responsive genes were assessed. Additionally, 120 days after germination (at the end of the season), agronomic traits were recorded. Analysis of the agronomical traits revealed higher productivity in the salt-pretreated group (priming+shock) plants than the non-pretreated (shock only). Consistently, saltpretreated plants maintained higher photosynthetic pigments level and decreased proline and MDA content than non-pretreated, suggesting enhanced salt tolerance. Moreover, salt-pretreated plants sustained high expressional levels of salt-responsive genes ( TaNHX1, TaSOS1, TaSOS4, TaHKT1, TaHKT2, and TaAKT1) comparing with non-pretreated, indicating a vital role in ion homeostasis and conferring salt tolerance. Ultimately, this finding could facilitate novel smart approaches to improve wheat productivity under salt stress.

Keywords: gene expression; priming; $\mathrm{NaCl}$; salt; stress; Triticum aestivum; wheat

Received: 19 Mar 2021. Received in revised form: 18 Apr 2021. Accepted: 06 May 2021. Published online: 10 May 2021.

From Volume 49, Issue 1, 2021, Notulae Botanicae Horti Agrobotanici Cluj-Napoca journal uses article numbers in place of the traditional method of continuous pagination through the volume. The journal will continue to appear quarterly, as before, with four annual numbers.
\end{abstract}




\section{Introduction}

Bread wheat (Triticum aestivum L.) is one of the three most widely consumed cereals (maize, rice, and wheat) worldwide. It is grown in many countries and greatly participates in the global agricultural economy. According to FAO, wheat provides one-fifth of food calories and proteins to the world population (FAO 2011). By 2050, it is expected that wheat demand rises by $60 \%$ in the developing countries due to the expected increase in the global population (Bodirsky et al., 2015). The gap between wheat production and consumption must be filled to meet increasing future food issues (Godfray et al., 2010; Shiferaw et al., 2011). The production of wheat as well as other cereals and several other crops is limited by various abiotic and biotic constraints (Majeed et al., 2018).

Salinity represents one of the most severe abiotic challenges that must be overcome to fill this gap (Elshafei et al., 2019). Almost 20\% of total cultivated land and 33\% of irrigated lands are affected by salinity stress, which is considered a leading cause of the loss of crop yields and production. It was estimated that salinized lands increase $10 \%$ annually, and consequently, it may reach $50 \%$ or more by 2050 , which would be significantly reflected on the agricultural output worldwide. Different factors control this increase like the rapid growth of human population, land salinization, scarce water resources, high surface evaporation, low precipitation, irrigation with saline water, weathering of native rocks and poor cultural practices (Pitman et al., 2002; Jamil et al., 2011; Saade et al., 2016; Soda et al., 2016; Dawi et al., 2021).

Crops grown on saline soils not only suffer from high osmotic stress, but also, nutritional disorders and toxicities, bad soil physicochemical conditions and consequently reduced crop productivity (Shao et al., 2016). Besides exerting osmotic stress, soil salinity often creates water-deficit conditions in the form of physiological drought (Zhao et al., 2016; Zhang et al., 2017; El-Beltagi et al., 2020a, b).

Soil salinity affects wheat plants in different aspects and stages; it suppresses seedling germination and emergence, disrupts many physiological processes like protein synthesis, enzyme activity, membrane integrity, cell division (Farooq et al., 2015; Mohamed et al., 2018). It may also speed up senescence with a gradual decrease in chlorophyll (Shoresh et al., 2011). Consequently, bread wheat showed a decreased yield with the increase of salinity of the irrigation water. When the salinity of the irrigation water was $2-3 \mathrm{gm} / \mathrm{L}$, the wheat yield was reduced by $7 \%-13 \%$ and was reduced by $13-24 \%$ when the salinity of the irrigation water was $3-5 \mathrm{gm} / \mathrm{L}$.

Seeds priming is a physiological technique achieved by soaking the seeds in different solutions of different concentrations for different periods to enhance imbibition capacity and the pre-germinative metabolic process to ensure rapid germination, improved seedlings growth, vigor, and final yield under normal and stress conditions as well (Varier et al., 2010; Paperella et al., 2015; Salah et al., 2015; Sano et al., 2017). So, plant priming is a kind of hardening and sensitizing plants by exposing them to initial environmental stresses that function as reminders for plants to enter the primed state when exposed to the same environmental stress; primed plants have shown to be stimulated to provoke defensive processes faster than unprimed plants (Filippou et al., 2013; Sani et al., 2013). Recently, stress-induced priming and associated memory is an intriguing adaptive response in plants and has important implications for crop development and improvement.

Many reports proved that salt priming could improve plant tolerance to salt stress. Salt priming can help plants acclimate to lethal salinity by enhancing osmotic adjustment and repressing ionic toxicity, indicated by the lowered $\mathrm{Na}^{+}$concentration and increased accumulation of osmolytes in salt-pretreated plants. Adaptation strategies suitable for different crops and regions offer a simple alternative for the development of crops tolerant to abiotic stress, ensuring food security (Salah et al., 2015).

'Priming' allows such acquired stress tolerance and offers many advantages: there is no introgression of an external genomic entity and it involves sub-lethal stress-mediated reprogramming of the molecular machinery to achieve enhanced tolerance; it is relatively fast; it is applicable for diverse stress conditions; and, with some optimization, it is capable of enhancing tolerance in a range of crops (Filippou et al., 2013).

Plant intracellular balance of the $\mathrm{K}^{+} / \mathrm{Na}^{+}$ratio plays a crucial role in living cells' physiological processes and is very important for normal plant growth (Chen et al., 2007; Shabala and Cuin, 2008). This is because the 
optimum ratio of $\mathrm{K}^{+} / \mathrm{Na}^{+}$affects many cytosolic enzymes' activities, maintaining the ideal osmotic pressure and plasma membrane potential for different cell regulations (Zhu, 2003). Salinity stress disturbs the intracellular balance of this $\mathrm{K}^{+} / \mathrm{Na}^{+}$ratio, which consequently causes ionic toxicity, osmotic stress and oxidative stress in plants (Zhu, 2003; Chen et al., 2007; Shabala and Cuin, 2008; Zhao et al., 2020). Plants have evolved different strategies to maintain the optimal cytosolic $\mathrm{K}^{+} / \mathrm{Na}^{+}$ratio and prevent these harmful effects of salinity stress on plant growth and development.

Different known genes were isolated from halophytic plants like antiporters (NHX, SOS, HKT) and were then employed to develop salt stress-tolerant crop plants. Stress-responsive genes such as the Salt Overly Sensitive (casually named SOS) gene family which play a crucial role in ion homeostasis, therefore conferring salt tolerance (Liu et al., 2000; Shi et al., 2000; Oh et al., 2010; Feki et al., 2011). The signalling pathway of SOS is made of three main proteins, SOS1, SOS2, and SOS3. It was shown that overexpression of SOS1 confers salt tolerance in different plant species (Shi et al., 2000; Ishitani et al., 2000; Feki et al., 2011), as it codes for plasma membrane $\mathrm{Na}^{+} / \mathrm{H}^{+}$antiporter which plays a significant role in the regulation of $\mathrm{Na}^{+}$efflux in the cell and facilitates the transport of $\mathrm{Na}^{+}$from the root system to the shoot system. HKT (histidine kinase transporter) family also play an important role in salt tolerance by regulating the transportation of $\mathrm{Na}^{+}$and $\mathrm{K}^{+}$, and thus prevent the excess accumulation and/or removal of excess $\mathrm{Na}^{+}$in leaves, therefore offer protection of the photosynthetic tissues from $\mathrm{Na}^{+}$toxic effect (Schroeder et al., 2013). Intracellular NHX proteins are $\mathrm{Na}^{+}$, $\mathrm{K}^{+} / \mathrm{H}^{+}$antiporters involved in ions $\left(\mathrm{Na}^{+}, \mathrm{K}^{+}, \mathrm{H}^{+}\right)$homeostasis (Barragán et al., 2012; Gálvez et al., 2012). Consequently, it has become necessary to study and cover all agronomical, physiological, biochemical, and molecular aspects of salt tolerance and the efficiency of modern approaches such as salt-priming to improve wheat productivity smartly and safely (Sairam et al., 2002; Gupta et al., 2014).

Therefore, this study investigates the effect of the salt-induced priming approach to cope with the salinity stress on wheat plants by measuring agronomical and physiological traits and the gene expression of some salt-responsive genes in wheat.

\section{Materials and Methods}

\section{Plant material and experimental design}

In order to test the effectiveness of salt-induced priming approach to improve the productivity of wheat plants, a pot experiment was carried out in the experiment farm of Agricultural Genetic Engineering Research Institute (AGERI), Agricultural Research Center (ARC), Giza, Egypt during the winter season of 2019/2020. Irrigation was scheduled based on crop water requirement and gap in rainfall.

In the present study, thirteen wheat cultivars were used (Table 1). Factorial experiment with two factors were designed in a completely randomized design with three replications. The treatments were designed as factor A: four different types of treatments in terms of salt stress application: control (Ctrl), priming only, priming+ shock and shock only, as shown in (Figure 1). Factor B: thirteen different wheat cultivars are varying from sensitivity to tolerance to salt stress.

Seeds were planted in plastic pots $(30 \mathrm{~cm}$ in width/ $3 \mathrm{~L}$ ), each containing a mixture of sandy soil and peat moss $(1: 1, \mathrm{v}: \mathrm{v})$. Five wheat seeds were sown in each pot. Three pots were used as replicates per treatment. After the seedling establishment, four uniform and healthy plants were allowed to grow in each pot and fertilized regularly using a standard dose of N:P:K 20:20:20 (1 g/L). The salinity treatment was applied thirty days after sowing using a fixed amount of salt solution for each treated pot. The salt solution was freshly prepared by dissolving a calculated amount of $\mathrm{NaCl}$ with tap water. The salt solution was added in increment concentrations every three days until the final concentration of $250 \mathrm{mM} \mathrm{NaCl}$ was achieved to apply the salt stress in a gradual exposure approach (salt priming) as shown in (Figure 1). After one week, under the final concentration of $250 \mathrm{mM} \mathrm{NaCl}$ the plants were irrigated with tap water. 


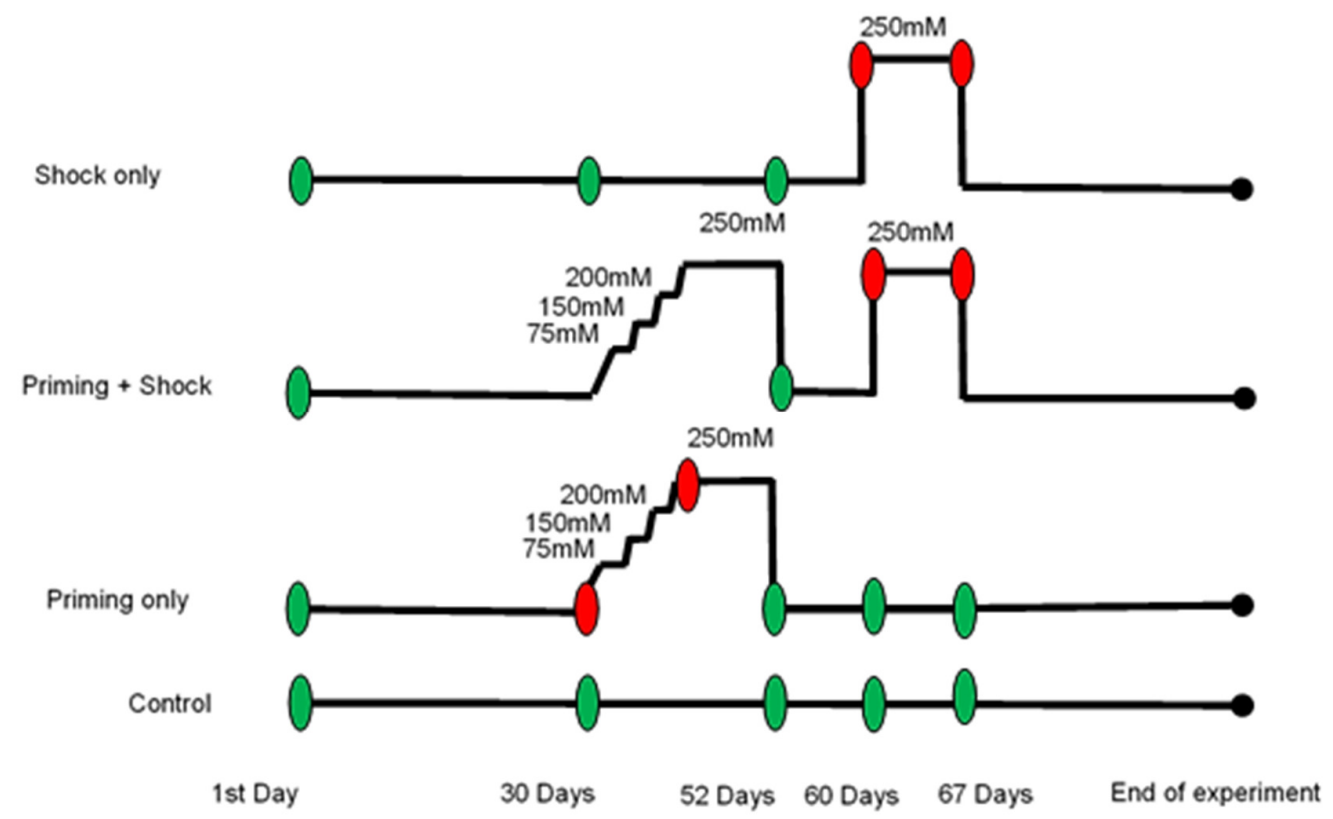

Figure 1. Scheme of the experimental setup

Horizontal lines represent different plant treatments as follows: control, priming only, priming + shock and shock only. Samples for physiological and gene expression analysis were collected at 67 days after sowing (at the end of the salt shock). Wheat yield was harvested at the end of experiments to calculate the total yield per plant

Table 1. Code of the 13 wheat cultivars, names and their origin

\begin{tabular}{|l|c|c|}
\hline \multicolumn{1}{|c|}{ Code } & Cultivar Name & Origin \\
\hline Cv.1 & 'Sids14' & Sids, Egypt \\
\hline Cv.2 & 'Giza171' & Giza, Egypt \\
\hline Cv.3 'Giza168' & Barida, KSA \\
\hline Cv.4 & 'Maiaa' & Tamir, KSA \\
\hline Cv.5 & 'Henta Asmr' & Najran, KSA \\
\hline Cv.6 & 'Asmr' & Alehsaa, KSA \\
\hline Cv.7 & 'Molloaha Mokaom' & Elkharag, KSA \\
\hline Cv.8 & 'Samaa Baladi' & Tamir, KSA \\
\hline Cv.9 & 'Samaa Baladi' & Tamir, KSA \\
\hline Cv.10 & 'Soariak' KSA \\
\hline Cv.11 'Samaa' & Barida, KSA \\
\hline Cv.12 & 'Helba' & Barida, KSA \\
\hline Cv.13 & 'Lokami' & \\
\hline
\end{tabular}

Physiological parameters screening

Photosynthetic pigments

Photosynthetic pigments (chlorophyll a, chlorophyll b, total chlorophyll and carotenoids) were determined using the spectrophotometric method (Atia et al., 2020). 50mg fresh leaf tissues freshly grounded in liquid nitrogen and soaked in $0.5 \mathrm{ml} 80 \%$ acetone to extract the pigments for one week. The slurry was centrifuged at $10000 \mathrm{~g}$ for $10 \mathrm{~min}$ and the debris was washed with $0.5 \mathrm{ml} 80 \%$ acetone ice cold. The supernatants were pooled and completed to a certain volume with acetone. The extract's absorbance was measured spectrophotometrically against a blank of 80\% acetone at three different wavelengths, $440.5,644$ and $662 \mathrm{~nm}$. 
The concentration of each pigment was calculated using the following formula described by Sestak et al. (1971). The results were expressed as $\mu \mathrm{g}$ pigment $\mathrm{g}^{-1} \mathrm{FW}$.

Chlorophyll a $\left(\mu \mathrm{g} \mathrm{g}^{-1} \mathrm{FW}\right)=9.78 \mathrm{E} 662-0.99 \mathrm{E} 644$

Chlorophyll b $\left(\mu \mathrm{g} \mathrm{g}^{-1} \mathrm{FW}\right)=21.4 \mathrm{E} 644-4.65 \mathrm{E} 662$

Chlorophyll $(\mathrm{a}+\mathrm{b})\left(\mu \mathrm{gg}^{-1} \mathrm{FW}\right)=5.13 \mathrm{E} 662+20.41 \mathrm{E} 644$

Carotenoids $(\mathrm{Car})\left(\mu \mathrm{g} \mathrm{g}^{-1} \mathrm{FW}\right)=4.69 \mathrm{E} 440.5-(\mathrm{Ch} \mathrm{a}+\mathrm{Ch} \mathrm{b}) \mathrm{x} 0.268$

All extraction steps were carried out in dim light through a maximum of six hours to avoid the decomposition of pigments.

Lipid peroxidation (MDA)

Malondialdehyde (MDA) content of the flag leaf was estimated (Heath and Packer, 1968). The leaves were collected in liquid nitrogen and deposited at $-80{ }^{\circ} \mathrm{C}$ till performing the MDA assay. OD600 values are subtracted from the MDA-TBA complex values at $532 \mathrm{~nm}$ and MDA concentration is calculated using the Lambert-Beer law with an extinction coefficient $\varepsilon \mathrm{M}=155 \mathrm{mM}^{-1} \mathrm{~cm}^{-1}$. Results are presented as nmols MDA g ${ }^{1} \mathrm{FW}$.

Proline content

The proline content of the flag leaf was estimated according to Shabnam et al. (2016) and Abdelaziz et al. (2019). The leaves were collected in a paper bag and completely dried in the oven at $70{ }^{\circ} \mathrm{C}$ till constant weight was obtained. The proline content was determined from a standard curve and calculated on a dry weight basis as follows:

$\mu$ moles proline $\mathrm{g}^{-1}$ of fresh plant material $=\left\{\left(\mu \mathrm{g}\right.\right.$ proline $\mathrm{mL}^{-1} \times \mathrm{mL}$ toluene $\left.) / 115.5 \mu \mathrm{g} \mu \mathrm{mole}^{-1}\right\} /(\mathrm{g}$ sample/5)\}

\section{Agronomical evaluation}

Agronomical traits were measured 120 days after germination (at the end of the season) before harvest. The traits included: plant height $(\mathrm{cm})$, and number of tillers and spikes/plant, main spike length $(\mathrm{cm})$, number of spikelets/spike, number of grains/plant, the total yield/plant and weight of 1000 grains (g).

\section{$R N A$ isolation and $q R T-P C R$ analysis}

Fifteen days' post priming application (67 days after germination), the leaves of control and treatment plants were collected from three replicates in liquid nitrogen. RNA was isolated with Trizol reagent and treated with DNase I (Cat Num.: EN0525, Thermo Scientific). The cDNA was synthesized using the SuperScript ${ }^{\mathrm{m}}$ II Reverse Transcriptase as outline by the manufacturer's manual (Cat Num.: 18064014, Thermo Scientific). Salt-responsive genes (TaNHX1, TaSOS1, TaSOS4, TaHKT1, TaHKT2, and TaAKT1); and Ta Actin as a housekeeping gene were used for qRT-PCR analysis (Table 2). The qRT-PCR analysis was done using a StepOnePlus ${ }^{\text {Tw }}$ Real-Time PCR System (Thermo Fisher Scientific Inc., Waltham, MA, USA). The qPCR reaction in a final volume of $20 \mu \mathrm{L}$ contained $1 \mu \mathrm{L}$ of cDNA template, $0.5 \mu \mathrm{L}$ of gene-specific primers $(10 \mu \mathrm{M})$, $10 \mu \mathrm{L}_{\text {PowerUp }} \mathrm{p}^{\mathrm{mw}} \mathrm{SYBR}^{\mathrm{mi}}$ Green Master Mix (Applied Biosystems ${ }^{\mathrm{mw}}$ ), and $7.6 \mu \mathrm{LddH}_{2} \mathrm{O}$. The thermal cycles were $94^{\circ} \mathrm{C}$ for $30 \mathrm{~s}, 40$ cycles of $94^{\circ} \mathrm{C}$ for $5 \mathrm{~s}$ and $60{ }^{\circ} \mathrm{C}$ for $30 \mathrm{~s}$ and were followed by a dissociation stage. Each sample was repeated three times as technical repeats. The 2- $\Delta \Delta \mathrm{Ct}$ method was used for calculating the relative expression levels (Eisaa et al., 2017; Mohammed et al., 2017; Mokhtar and Atia, 2019). Three biological replicates (3 plants/treatment) were evaluated, and the mean and standard deviation values of statistics were measured. 
Table 2. Gene names, primers sequences used for qRT-PCR analysis and their references

\begin{tabular}{|c|c|c|c|}
\hline Gene Name & Primer $\mathrm{F}$ & Primer R & Ref \\
\hline TaNHX1 & GCCGGGTTTCAAGTAAAG & GGACTATCTTGCAATTGGG & $\begin{array}{c}\text { (Zeeshan et } \\
\text { al., 2020) }\end{array}$ \\
\hline TaSOS1 & GTTGTCGGTGAGGTCGGAGGG & ТСАТСТTСТССТАССGСССТGC & \multirow{2}{*}{$\begin{array}{c}\text { (Ramezani et } \\
\text { al., 2013) }\end{array}$} \\
\hline TaSOS4 & ATCCAGTCCCACACCGTCCA & GCTGATTGCCATTGAGAACCTGTC & \\
\hline TaHKT1 & ACCTCGCCATCTTCATCATC & GCTTCCATGAAGGAAACCAA & \multirow{2}{*}{$\begin{array}{c}\text { (Kumar et al., } \\
\text { 2017) }\end{array}$} \\
\hline TaHKT2 & TATGTGATGAGTCGCAGCTTGAA & GCAACAAGAGGCCTGAATTCTTT & \\
\hline$T a A K T 1$ & CGGATAATGCCGTGAATG & TTATACTATCСТССАTGCCT & $\begin{array}{c}\text { (Zeeshan et } \\
\text { al., 2020) }\end{array}$ \\
\hline Ta-Actin & GACAATGGAACCGGAATGGTC & GTGTGATGCCAGATTTTCTCCAT & $\begin{array}{c}\text { (Zeeshan et } \\
\text { al., 2020) }\end{array}$ \\
\hline
\end{tabular}

Statistical analysis

Experiments were carried out following a randomized complete block design with three replicates. Data normality and the homogeneity of variances were checked using the Kolmogorov-Smirnov test and Levene's test, respectively. All the data was subjected to one-way Analysis of Variance (ANOVA). Tukey's Multiple Comparisons Test $(\mathrm{p} \leq 0.05)$ was carried out as the post-hoc test for mean separations. Also, Pearson correlation was calculated to determine the correlation between measured traits. All statistical tests were performed using the computer program SPSS statistics 25 (SPSS Inc., Chicago, IL, USA).

\section{Results}

To fulfill our aim, we designed the experimental groups (control, priming, priming+shock and shock) to study the effects of the salt-induced priming approach on the agronomic traits (total yield/plant (g/plant), 1000 kernels weight $(\mathrm{g})$, spike length $(\mathrm{cm})$, number of kernels/spike, number of spikelets/spike, shoot dry weight $(\mathrm{g})$, peduncle length $(\mathrm{cm})$, and plant height $(\mathrm{cm})$ ), physiological parameters (proline, MDA, chlorophyll 'a', 'b', total chlorophyll, and carotenoids) and the expression level of some salt-responsive genes ( TaNHXI, TaSOS1, TaSOS4, TaHKT1, TaHKT2, and TaAKT1). Thirteen wheat cultivars (three Egyptian cultivars and ten Saudi cultivars) were used to investigate and compare their performance under the salt-induced priming approach.

\section{Agronomic traits evaluation}

A total of eight agronomic traits (peduncle length $(\mathrm{cm})$, plant height $(\mathrm{cm}), 1000$ kernels weight $(\mathrm{g})$, spike length $(\mathrm{cm})$, number of kernels/spike, number of spikelets/spike, shoot dry weight $(\mathrm{g})$ and total yield/plant $(\mathrm{g} / \mathrm{plant}))$ were evaluated to reflect the usefulness of salt-induced priming approach to improving different yield component traits under salt stress. Comparative evaluation of the 13 wheat cultivars under control and salt stress conditions demonstrated that all the salt-stressed groups exhibited consistent patterns of decrease compared to the control, particularly for the salt-pretreated group (priming+shock), which always takes an intermediate value between the non-pretreated group (shock only) and the priming group (Figures $2 \mathrm{~A}-\mathrm{H}$ ).

The correlation analysis between the eight agronomic traits revealed the highest correlation between the spike length and the number of spikelets/spike traits (0.833). Also, a high correlation was observed between the total yield/plant trait and both thousand-Kernels Weight and the number of Kernels/ Spike traits $(0.682$ and 0.678 , respectively) (Table 3 ).

From another perspective, the heatmap manifests a panoramic appearance for the eight agronomic traits (Figure 3A). The heatmap clustered the priming group with the control group. Notably, among the thirteen wheat cultivars, the cultivar Cv.5 appeared to have the lowest values for the thousand-Kernels Weight, the 
number of kernels/spike, the shoot dry weight, and the total yield/plant traits comparing with all other cultivars.

Table 3. Pearson correlation analysis between the eight agronomical traits

\begin{tabular}{|l|c|c|c|c|c|c|c|c|}
\hline \multicolumn{1}{|c|}{ Trait } & $\begin{array}{c}\text { Total } \\
\text { yield/ } \\
\text { plant }\end{array}$ & $\begin{array}{c}1000 \\
\text { kernels } \\
\text { weight }\end{array}$ & $\begin{array}{c}\text { Spike } \\
\text { length }\end{array}$ & $\begin{array}{c}\# \\
\text { Kernels } \\
/ \text { Spike }\end{array}$ & $\begin{array}{c}\# \\
\text { Spikelets } \\
\text { /Spike }\end{array}$ & $\begin{array}{c}\text { shoot dry } \\
\text { weight }\end{array}$ & $\begin{array}{c}\text { Peduncle } \\
\text { length }\end{array}$ & $\begin{array}{c}\text { Plant } \\
\text { height }\end{array}$ \\
\hline Total yield/plant & 1 & $0.682^{* *}$ & $0.413^{* *}$ & $0.678^{* *}$ & $0.319^{* *}$ & $0.443^{* *}$ & $0.414^{* *}$ & $0.404^{* *}$ \\
\hline 1000 kernels weight & $0.682^{* *}$ & 1 & $0.281^{* *}$ & $0.358^{* *}$ & $0.191^{*}$ & $0.444^{* *}$ & $0.352^{* *}$ & $0.322^{* *}$ \\
\hline Spike length & $0.413^{* *}$ & $0.281^{* *}$ & 1 & $0.454^{* *}$ & $0.833^{* *}$ & $0.360^{* *}$ & $0.332^{* *}$ & $0.437^{* *}$ \\
\hline \# Kernels/ Spike & $0.678^{* *}$ & $0.358^{* *}$ & $0.454^{* *}$ & 1 & $0.376^{* *}$ & $0.324^{* *}$ & $0.302^{* *}$ & $0.339^{* *}$ \\
\hline \# Spikelets/ Spike & $0.319^{* *}$ & $0.191^{*}$ & $0.833^{* *}$ & $0.376^{* *}$ & 1 & $0.259^{*}$ & $0.303^{* *}$ & $0.338^{* *}$ \\
\hline Shoot dry weight & $0.443^{* *}$ & $0.444^{* *}$ & $0.360^{* *}$ & $0.324^{* *}$ & $0.259^{* *}$ & 1 & $0.423^{* *}$ & $0.560^{* *}$ \\
\hline Peduncle length & $0.414^{* *}$ & $0.352^{* *}$ & $0.332^{* *}$ & $0.302^{* *}$ & $0.303^{* *}$ & $0.423^{* *}$ & 1 & $0.547^{* *}$ \\
\hline Plant height & $0.404^{* *}$ & $0.322^{* *}$ & $0.437^{* *}$ & $0.339^{* *}$ & $0.338^{* *}$ & $0.560^{* *}$ & $0.547^{* *}$ & 1 \\
\hline
\end{tabular}

**. Correlation is significant at the 0.01 level (2-tailed).

*. Correlation is significant at the 0.05 level (2-tailed)

\section{Physiological parameters screening}

Regarding the effect of salinity stress on the physiological parameters (proline, MDA, chlorophyll 'a', 'b', total chlorophyll, and carotenoids), the shoot tissues of the experimental groups were collected after salt shock for seven days (at 67 days after germination).

\section{Photosynthetic pigments}

The photosynthetic pigments content of the wheat cultivars under study, including chlorophyll 'a', 'b', total chlorophyll, and carotenoids, were measured. The results revealed a decreased trend through the three salt-stressed groups (priming, priming + shock, and shock) compared to the control group. Although there is a general trend of decrease, the salt-pre-treated group (priming + shock) was outperforming the non-pre-treated group (shock only) with a relatively low decrease pattern in the chlorophyll 'a', 'b', total chlorophyll, and carotenoids contents (Figures 4A-D).

\section{Lipid peroxidation (MDA)}

Generally, increased lipid peroxidation (in terms of MDA level) content in plant tissues is a clear indicator of the reactive oxygen species levels and their damage to plant cells under salt-stress conditions. Notably, the cultivars Cv.5, Cv.6, Cv.7, Cv.12, and Cv.13 showed a significant increase (more than $2.5 \mathrm{nmol}$ $\mathrm{g}^{-1} \mathrm{FW}$ ) in the shock group compared to the control group. The priming group showed very close values to the control group. The values of the non-pre-treated group (shock only) were the highest among the three treatment groups. Also, the salt-pre-treated group (priming +shock) exhibited a trend of decreased MDA content than the non-pre-treated group (shock only) for all most of the cultivars. Except for the cultivars Cv.1, $\mathrm{Cv} .2$, and Cv.8, there were insignificant differences between the priming + shock and the shock groups in the MDA level (Figure 4E). 


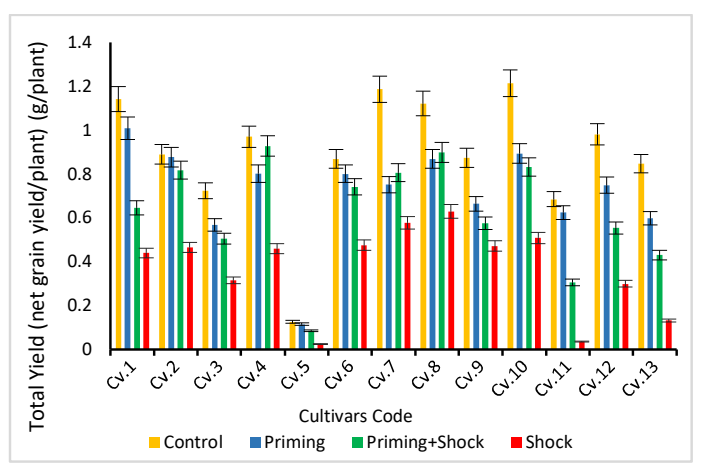

(A)

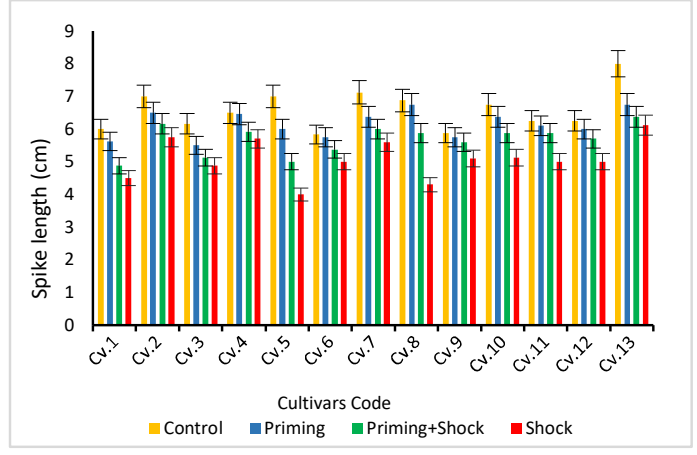

(C)

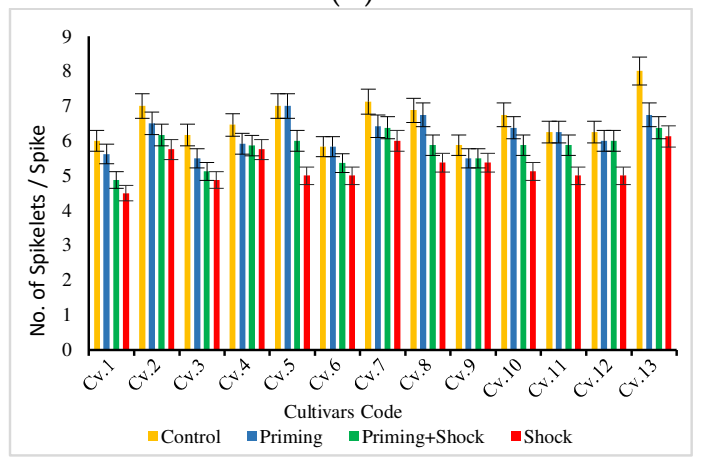

(E)

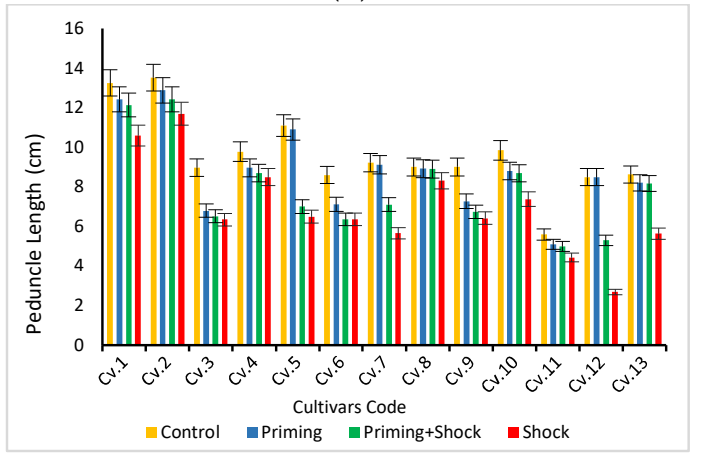

(G)

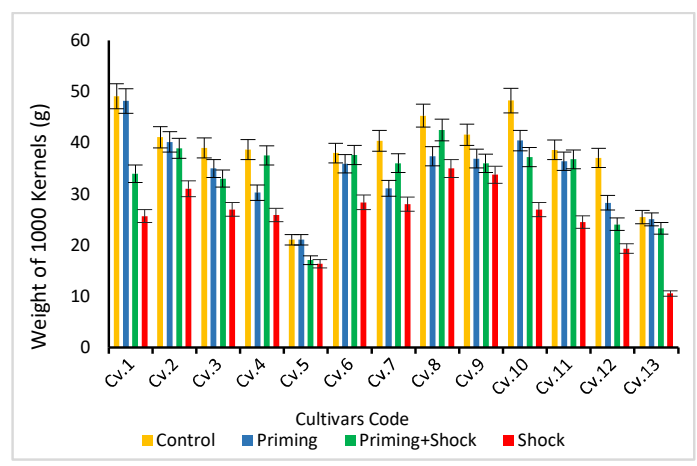

(B)

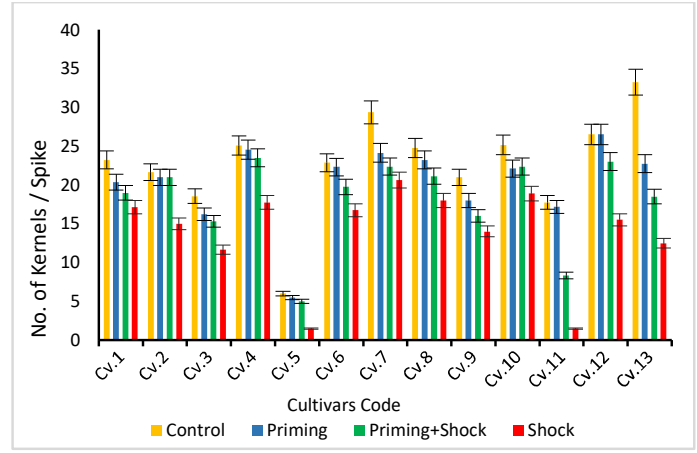

(D)

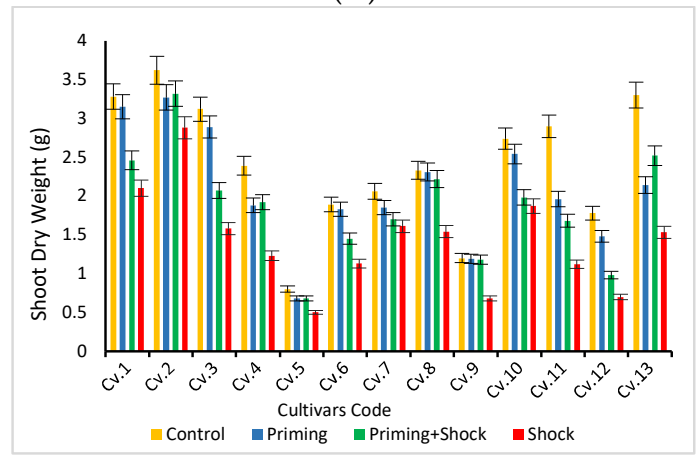

(F)

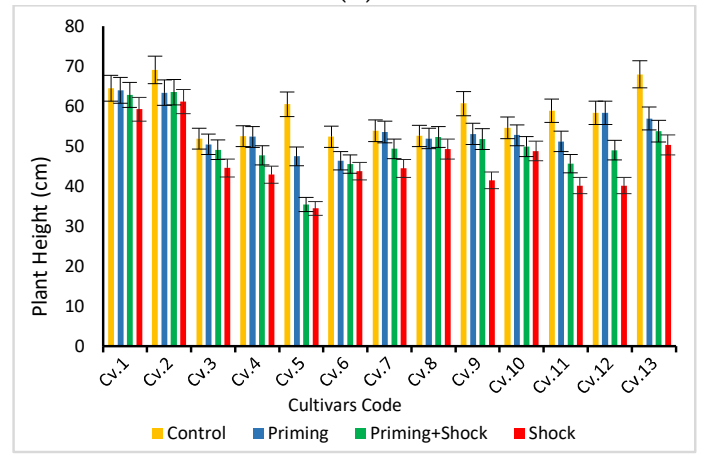

(H)

Figure 2. Effect of salinity stress of the salt-treated groups (priming, priming+shock, and shock) on the eight agronomic traits: (A) total yield/plant, (B) 1000 kernels weight, (C) spike length, (D) number of kernels/spike, (E) number of spikelets/spike, (F) shoot dry weight, $(\mathrm{G})$ peduncle length, and $(\mathrm{H})$ plant height. Tukey's Multiple Comparisons Test was conducted to ascertain the significant difference between means $(\mathrm{n}=3)$ at a significant level of $\mathrm{P}<0.05$ and represented as mean \pm standard deviation (SD). 


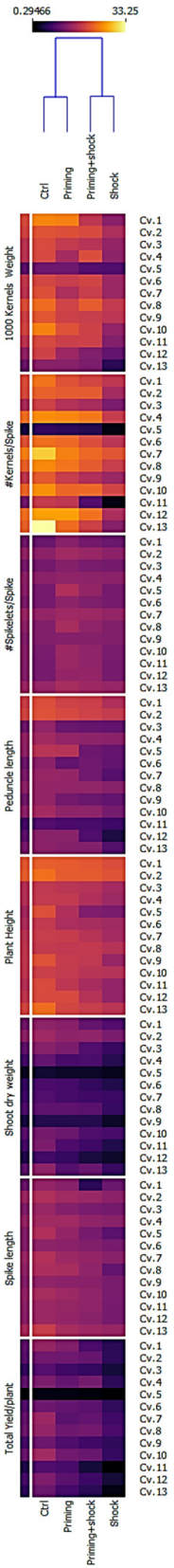

(A)

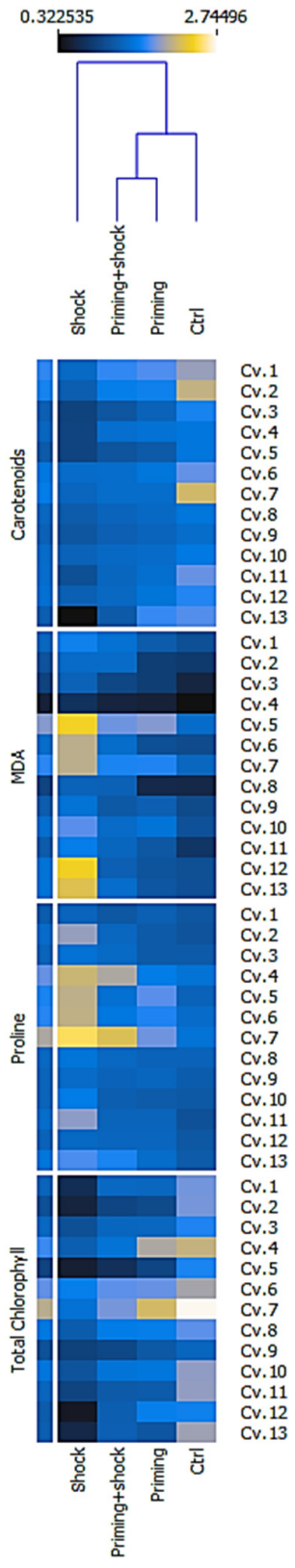

(B)

Figure 3. Two-dimensional heatmap visualization shows the interaction between the treatments (ctrl, priming, priming + shock and shock) and (A) the eight agronomic traits data, (B) the four physiological traits data of the 13 wheat accessions

\section{Proline content}

Generally, higher accumulation of the proline content is associated with salinity tolerance in wheat. The results showed a general trend of increase in the proline content in all groups compared to the control group, particularly in the shock group among the three salt-treated groups. The values of the salt-pretreated group (priming+shock) exhibited a general trend of decreased proline levels compared with the non-pretreated group (shock only). The priming group showed comparable levels for the control group. The results also revealed that 
cultivars Cv.4, Cv.5, Cv.6, and Cv.7 of the shock group showed a significant increase (more than $2 \mu \mathrm{mol} g$ ${ }^{1} \mathrm{FW}$ ). While the salt-pretreated (priming+shock) group showed decreased values in all cultivars, except for the cultivars Cv. 4, Cv.9, and Cv.13, which showed insignificant decrease between the non-pretreated group and the salt-pretreated group (Figure $4 \mathrm{~F}$ ).

The correlation analysis of the four measured physiological traits disclosed a robust positive correlation between Carotenoids-Total Chlorophyll and MDA-proline ( 0.655 and 0.636 , respectively). Meanwhile, the highest negative correlation was observed between Carotenoids-MDA (-0.550) (Table 4).

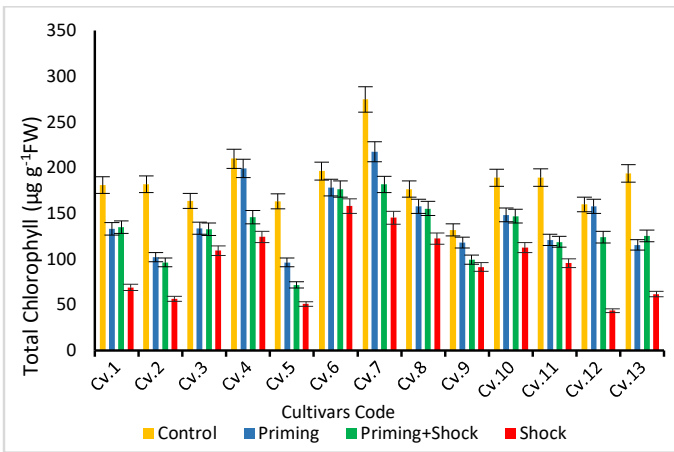

(A)

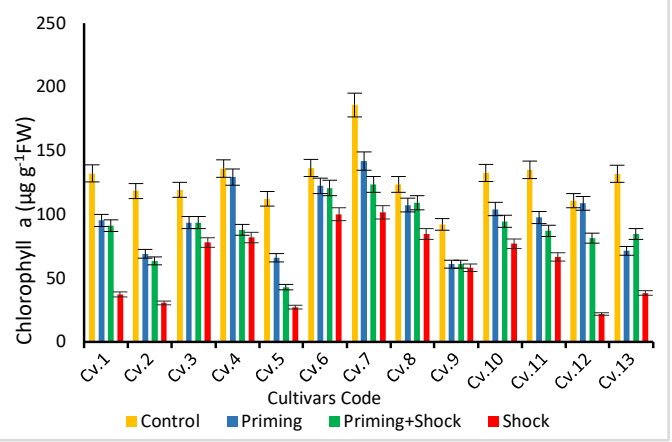

(C)

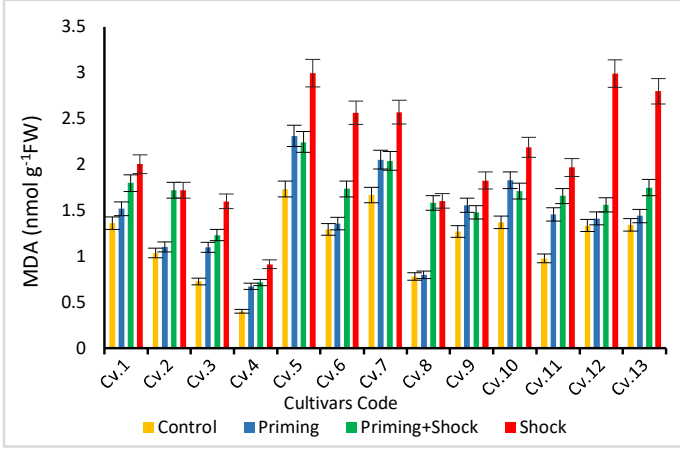

(E)

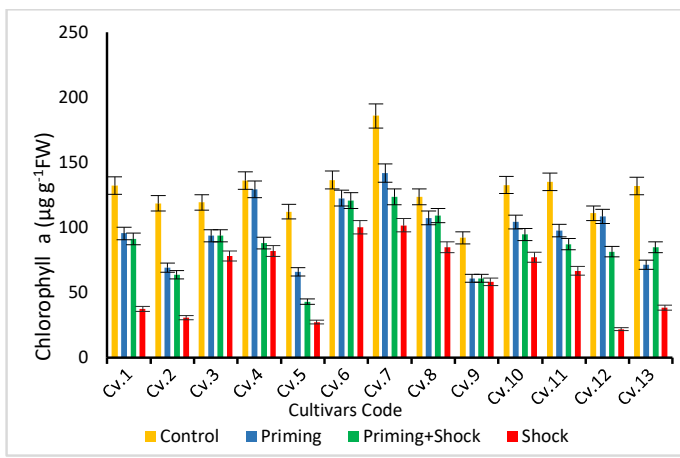

(B)

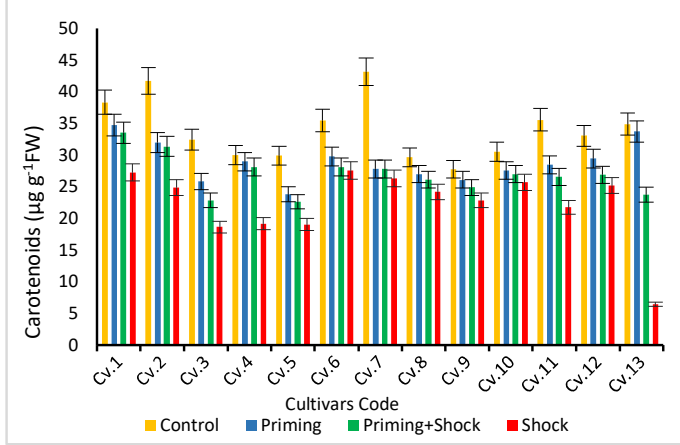

(D)

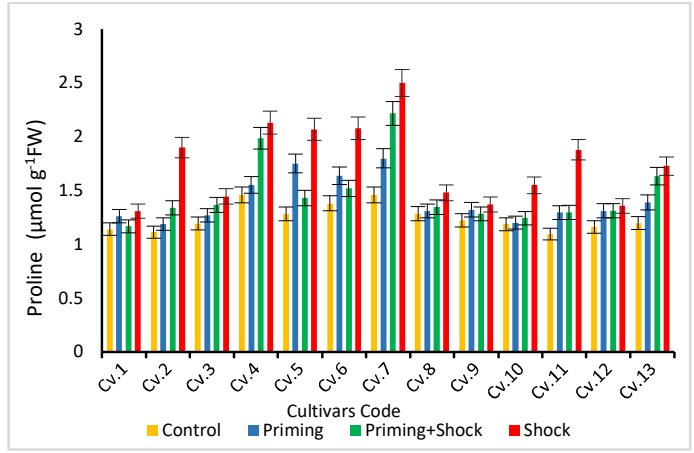

(F)

Figure 4. Overview of the changes in the physiological parameter's levels: (A) Total Chlorophyll, (B) Chlorophyll a, (C) Chlorophyll b, (D) Carotenoids, (E) MDA and (F) Proline of the salt-treated groups (priming, priming + shock, and shock)

Tukey's Multiple Comparisons Test was conducted to ascertain the significant difference between means $(n=3)$ at a significant level of $\mathrm{P}<0.05$ and represented as mean \pm standard deviation $(\mathrm{SD})$. 
From a broad view, the relationship between physiological parameters, as translated in heatmap representation, revealed that the priming, priming+shock, and control groups were clustered together while the shock group was separated from the other groups. Above all, the cultivar 'Cv.7' appeared to have the highest proline content within the thirteen cultivars (Figure 3B).

Table 4. Pearson correlation analysis between the physiological traits (proline, MDA, total chlorophyll and carotenoids) data

\begin{tabular}{|l|c|c|c|c|}
\hline & Proline & MDA & Total chlorophyll & Carotenoids \\
\hline Proline & 1 & $0.636^{* *}$ & -0.136 & $-0.340^{*}$ \\
\hline MDA & $0.636^{* *}$ & 1 & $-0.485^{* *}$ & $-0.550^{* *}$ \\
\hline Total chlorophyll & -0.136 & $-0.485^{* *}$ & 1 & $0.655^{* *}$ \\
\hline Carotenoids & $-0.340^{*}$ & $-0.550^{* *}$ & $0.655^{* *}$ & 1 \\
\hline
\end{tabular}

**. Correlation is significant at the 0.01 level (2-tailed).

*. Correlation is significant at the 0.05 level (2-tailed).

\section{Salt-responsive genes}

Quantitative Real-Time PCR (qRT-PCR) analysis was carried out to estimate the transcript levels of some of the salt-responsive genes, particularly genes participating in the ion transport process to achieve ion homeostasis. The expression patterns of the six antiporter genes named; TaNHX1, TaSOS1, TaSOS4, TaHKT1, TaHKT2 and TaAKT1 have quantitatively estimated in the leaves of wheat plants/groups subjected to long-term salinity stress as well as untreated control plants.

According to the expression levels of the TaNHX1 gene, it was upregulated significantly in the salt priming group compared to the control group. Meanwhile, it was upregulated in the salt-pretreated group (priming+shock) compared to the non-pretreated group (shock only). Nevertheless, it was noticed that its expression level in the non-pretreated group (shock only) was higher than that in the salt priming group (Figure $5 A)$.

Concerning the expression levels of the Salt Overly Sensitive (SOS) pathway-related genes (TaSOS1 and TaSOS4 genes) in response to long-term treatment of salinity stress, we found that both genes showed a significant increase, especially in the salt priming group compared to the control group. Both genes also showed an increased expression level in the salt-pretreated group (priming+shock) compared to the non-pretreated group (shock only). However, this increase was significant in the expression level of TaSOS1 and was not significant in the expression level of TaSOS4 (Figure 5B-C).

Regarding TaHKT1 and TaHKT2 genes, the qRT-PCR results revealed a significant rise in their expression levels, especially in the salt priming group compared to the control. It was also significantly increased in the salt-pretreated group (priming+shock) compared to the non-pretreated group (shock only). Notably, the expression level of the TaHKT2 was higher in the non-pretreated group (shock only) than in the salt priming group (priming only) (Figure 6A-B).

The expression level of $T a A K T 1$ was also significantly raised in the salt priming group (priming only) compared to the control group. Moreover, in the salt-pretreated group (priming+shock), the TaAKT1 expression level showed a significant increase compared to the non-pretreated group (shock only) (Figure 6C). 


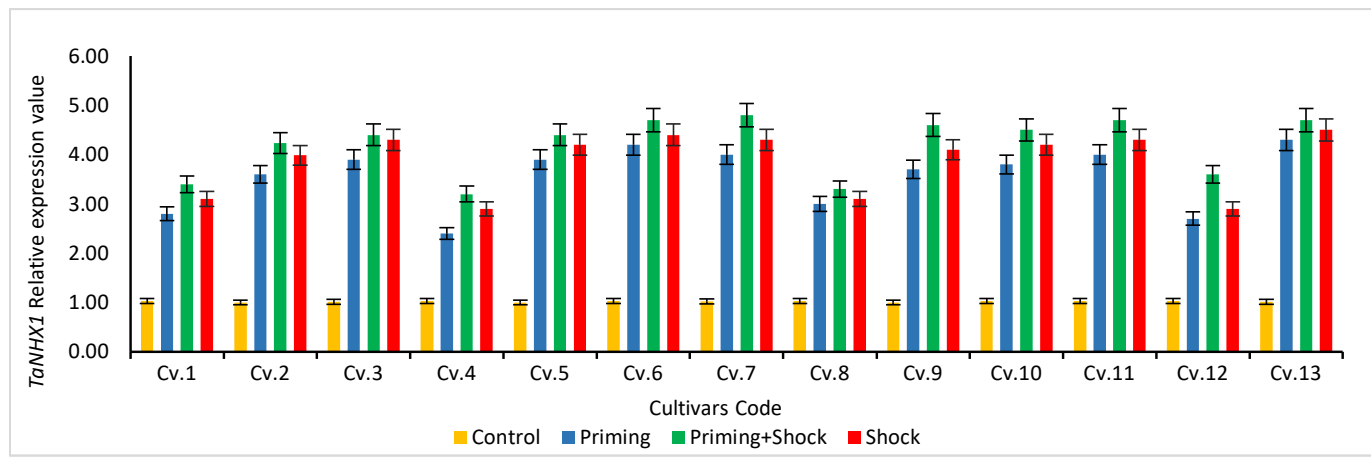

(A)

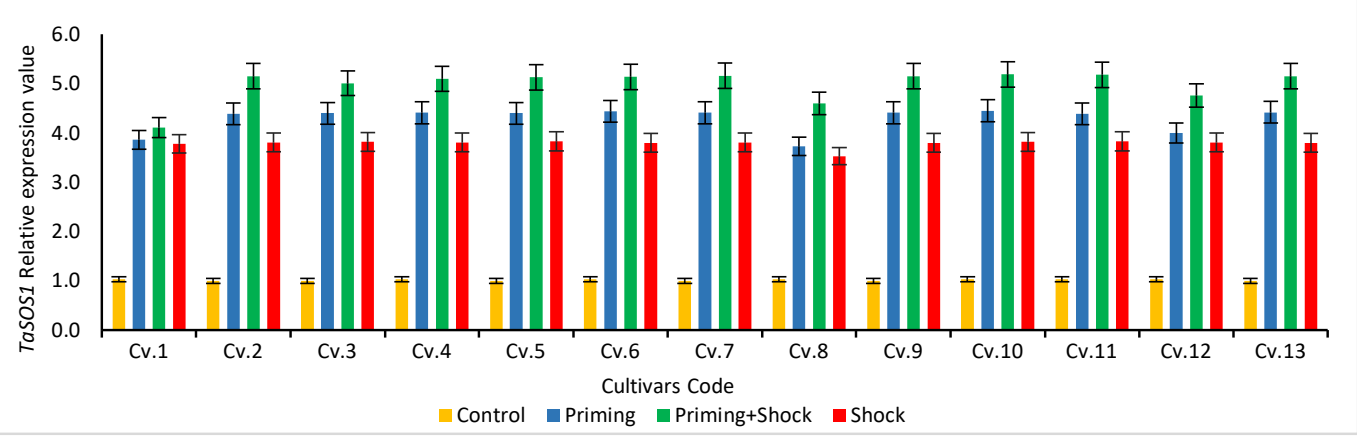

(B)

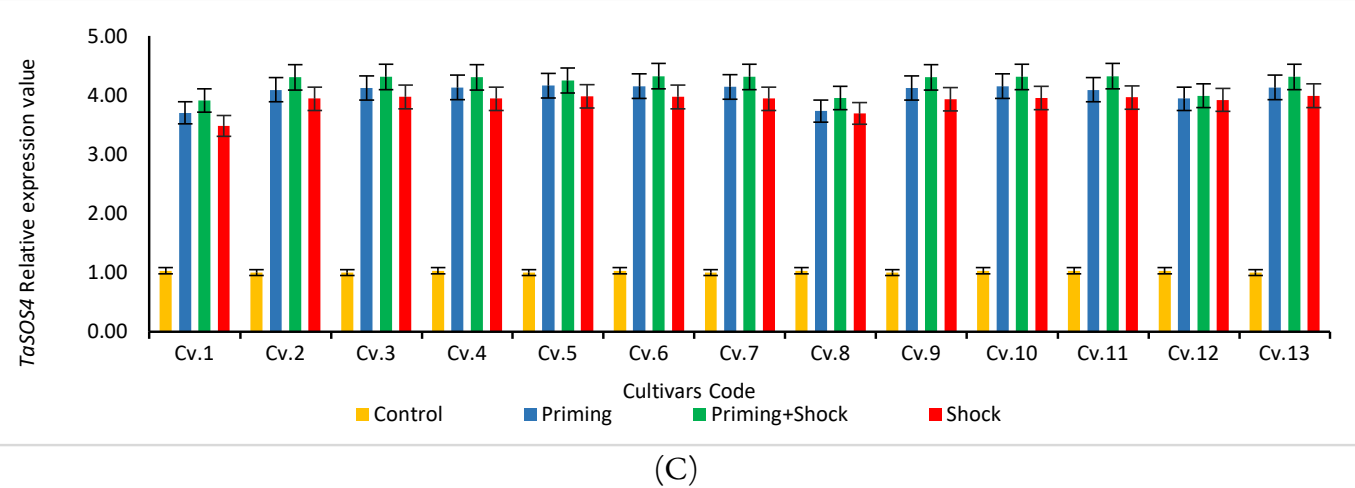

Figure 5. Expression analysis of (A) TaNHX1, (B) TaSOS1 and (C) TaSOS4antiporter gene in leaf tissues of the 13 wheat cultivars under the control, priming, priming + shock and shock conditions Tukey's Multiple Comparisons Test was conducted to ascertain the significant difference between means $(\mathrm{n}=3)$ at a significant level of $\mathrm{P}<0.05$ and represented as mean \pm standard deviation (SD). 


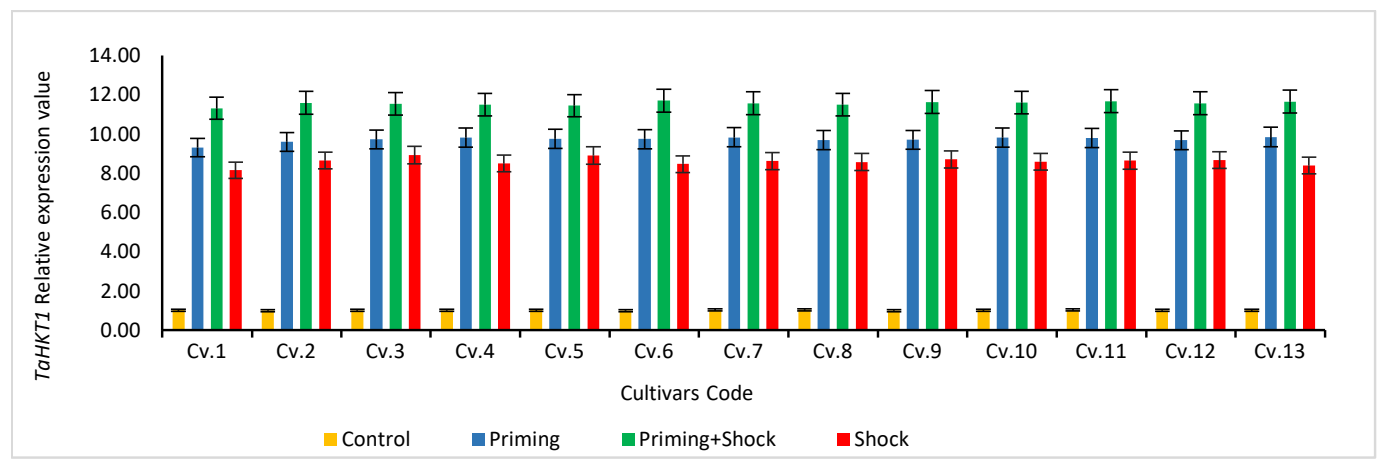

(A)

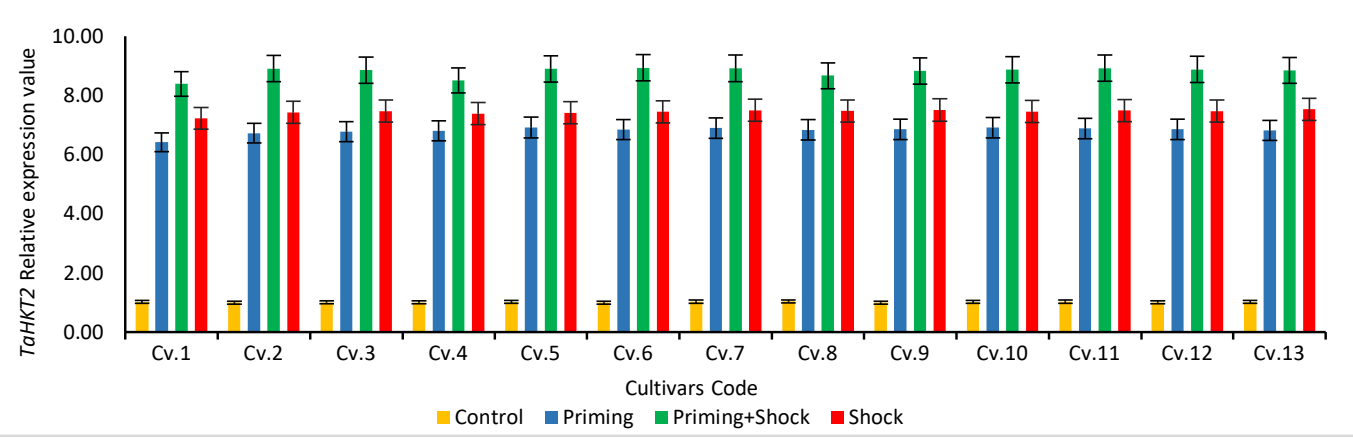

(B)

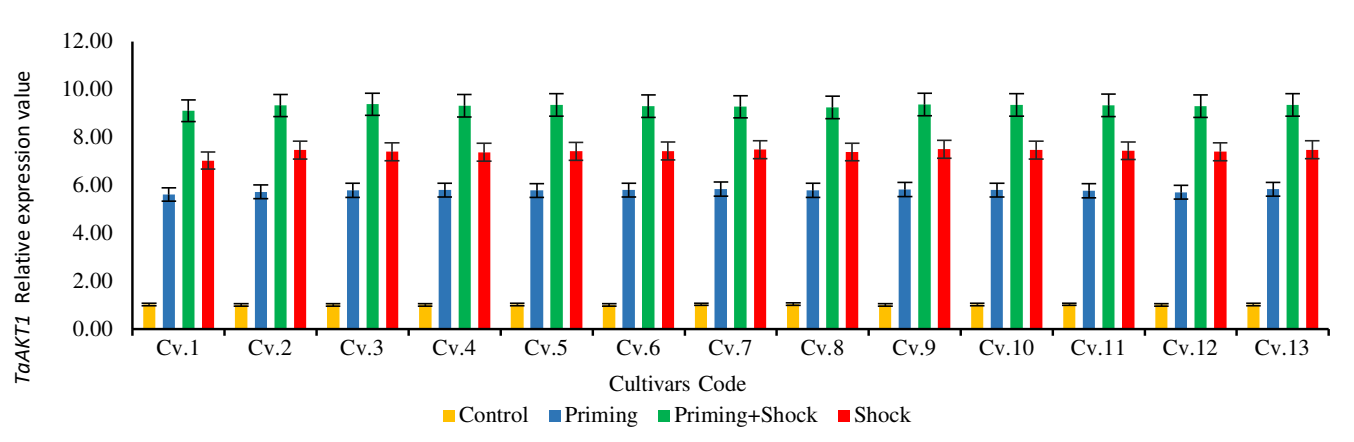

(C)

Figure 6. Expression analysis of (A) TaHKT1, (B) TaHKT2 and (C) TaAKT1 antiporter gene in leaf tissues of the 13 wheat cultivars under the control, priming, priming + shock and shock conditions Tukey's Multiple Comparisons Test was conducted to ascertain the significant difference between means $(\mathrm{n}=3)$ at a significant level of $\mathrm{P}<0.05$ and represented as mean \pm standard deviation (SD).

\section{Discussion}

Wheat (Triticum aestivum L.) is one of the world's most frequently consumed crop plants, which feeds an immense number of people. Attention in studying salt stress effects is overgrowing because salinity is now a major environmental factor limiting crop production (Alshehri et al., 2020). Salt stress inhibits photosynthetic activity and reduces plant growth by inducing osmotic stress and ionic toxicity (Chavez and Oliveira, 2004; Tari, 2016). Numerous studies demonstrated that salt stress's osmotic and ionic components represent primary and secondary phases of the stress, respectively, where plants react to each component at different times (Shavrukov, 2013). The ionic effect is a continuous, long-term effect of cumulative processes since it is dependent on the intracellular salt ion levels, which increase with the duration of salinity stress. Therefore, 
depending on the $\mathrm{NaCl}$ application method, whether in a single step or gradual, plants may experience either salt shock or salt stress, respectively.

Meanwhile, salt stress raises toxic ions concentration in plant cells, resulted in ion homeostasis disruption and consequently oxidative damage with excess production of reactive oxygen species (ROS) (Sani et al., 2013); salt priming proved to help plants acclimation to lethal salinity by improving osmotic adjustment and attenuating the ionic toxicity harmful effects (Djanaguiraman et al., 2018). Several approaches have been introduced to enhance the tolerance of plants against salinity, such as; osmo-priming with chemical compounds (polyethylene glycol (PEG), $\mathrm{KNO} 3, \mathrm{~K} 3 \mathrm{PO} 4, \mathrm{MgSO} 4, \mathrm{KCl}$, and $\mathrm{CaCl}$ ), seed priming and salt priming (or gradual exposure of $\mathrm{NaCl}$ ) (Yan, 2015). Many studies investigated the salt-induced priming approach for improving the salt tolerance of Sweet sorghum, Faba bean, and wheat (Yan, 2015; Qados, 2011).

To fulfill our aim, we designed our study to reveal the differences between the gradual exposure of salt stress (salt priming) and the sudden application of salt stress (salt shock) compared to the control (irrigated with tap water) and their impact on improving the salt tolerance of different wheat cultivars. Also, we investigated the effect of the salt priming without further salt shock compared to the control. Thirteen wheat cultivars from two countries (Egypt and Saudi Arabia) studied to compare Egyptian cultivars' performance versus the Saudi cultivars under our developed salt-induced priming approach. Also, we investigated the longterm salt stress effect on plant productivity by evaluating a robust set of agronomic traits, physiological parameters, and gene expression of six salt-responsive genes.

The harmful effect of salinity on the yield component traits was significant, depending on the salinity level and time of application (Qados, 2011). A close inspection of our obtained results revealed that the largest decrease in the total yield/plant, 1000 kernels weight, spike length, number of kernel/spike, number of spikelets/spike, shoot dry weight, peduncle length, and plant height traits were noted in the non-pretreated group (shock only) compared to the control. This performance might be due to the severe harmful effect of the sudden application of salinity stress. Furthermore, the salt-pretreated group (priming+shock) recorded a downward trend of decrease for the yield component traits than the non-pretreated group (shock only), supporting the hypothesis that salt-induced priming application before the shock seemed to provide a kind of salt-acclimatization. More precisely, the long-term application of salinity stress revealed an inverse relationship between salt concentrations and plants' productivity (Qados, 2011). Another previous supporting study reported that the shock-treated wheat plants experienced a higher stress level than the salt-induced primed in durum wheat (Almansouri et al., 1999).

The effect of the application of sudden and gradual exposure of salt stress on the content of the photosynthetic pigments disclosed an inverse relationship between the salt-stressed groups and the photosynthetic pigments. The osmotic and ionic stresses and the loss in essential ions imposed by salinity resulted in significant disturbances in the photosynthetic pigments (El-Hendawy et al,, 2019). The photosynthetic pigments were declined by increasing salinity (negatively correlated with the salinity conditions) (Pervaiz et al., 2002). The reduction in photosynthetic pigments might be due to the enhancement of chlorophyllase activity under salt stress conditions or the reduction in de novo chlorophyll synthesis (Hasson et al., 1983). Our results revealed that wheat plants under salt stress seemed to have "decreased" photosynthetic pigments values compared to the control group, supporting the previous results. The salt-induced priming approach's effect appeared to be superior for improving the salt tolerance of wheat plants; the salt-pretreated group (priming+shock) was outperforming the non-pretreated group (shock only) in the decrease of the photosynthetic pigments' contents. Our results were supported by the study derived by Qados et al. (2011) as they revealed that salt stress was an inhibiting factor for the formation of carotenoids inside the stressed plants.

As a consequence of salt stress development within a plant, all the major processes such as protein synthesis, lipid metabolisms, energy, and photosynthesis are severely affected (Parvaiz and Satyawati, 2008). Salinity tolerance is frequently attributed to plants' ability to accumulate low MDA content as a stress marker, indicating that they do not suffer from a high oxidative stress condition (negatively correlated with salt tolerance) (Kumar et al., 2017). Our results confirmed the negative correlation between the MDA content and 
salt tolerance; all the stressed groups (priming, priming+shock and shock) showed increased MDA content compared to the control group. However, the elite salt-pretreated group (priming+shock) was outperforming the non-pretreated group (shock only) with a decreased MDA contents, supporting better salt tolerance effect of the salt-induced priming approach. Our results agreed with the study conducted by Zou et al. (2016), in which they recorded an increase in the MDA accumulation by approximately $63 \%$ after ten days of salt stress conditions. For the cultivars Cv.6, Cv.12, and Cv.13, there was a notable difference between the priming+shock and the shock groups in the percentage relative to the control group, supporting the positive effect of the salt-induced priming approach on enhancing salt tolerance of the wheat plants. The general trend of decreased contents for the salt-pretreated group (priming+shock) than the non-pretreated group (shock only) when compared to the control group for all the thirteen cultivars supported the effect of the salt-induced priming approach on enhancing salt tolerance of the wheat plants.

Proline accumulation is a well-known mechanism that evolved to cope with the drought or salinity stress in several plant species (Parvaiz and Satyawati, 2008). Proline plays a crucial role in protecting the subcellular structures and mediating osmotic adjustment in stressed conditions (Rao et al., 2013). Our results revealed that the salt-pretreated group (priming+shock) seemed to be more salt-tolerant than the non-pretreated group (shock only; which is more susceptible to salt stress), supporting the positive effect of the salt-induced priming approach in improving the salt tolerance of wheat plants. Some cultivars recorded significant values; for the cultivars Cv.5, Cv.6, Cv.7, Cv.12, and Cv.13 the difference between the salt-pretreated group (priming+shock) and the non-pretreated group (shock only) was highly significant. Besides, Kanawapee et al. (2013) work on rice supported that the highly susceptible cultivars accumulated the highest proline level than the tolerant cultivars under salt stress.

The plant's ability to $\mathrm{Na}^{+}$compartmentalization into vacuoles provides an efficient mechanism to deal with the toxic effect of $\mathrm{Na}^{+}$in the cell cytosol level (Brini et al., 2007). The NHX and SOS gene-families transporters have been reported in wheat (Brini et al., 2005; Xu et al., 2013). These families act as $\mathrm{Na}^{+} / \mathrm{H}^{+}$ antiporter at the vacuolar level by transporting the $\mathrm{Na}^{+}$ions driven by the electrochemical proton gradient (Gaxiola et al., 1999). Higher expression of these endogenous genes reflects vacuolar $\mathrm{Na}^{+} / \mathrm{H}^{+}$antiporters' levels and is significantly correlated with salinity tolerance in wheat genotypes (Saqip et al., 2005; Benderradji et al., 2011; Cuin et al., 2011). Our results revealed that the expression of TaNHX1 was upregulated in the salttreated groups (priming, priming ${ }^{+}$shock and shock) compared to the control. Notably, the salt-pretreated group (priming ${ }^{+}$shock) was outperforming the non-pretreated group (shock only) by boosting the TaNHXI expression levels, supporting the salt-induced priming effect approach in enhancing the salt tolerance levels in wheat plants under salt-stress conditions. The results disclosed an agreement with the previous work of Zeeshan et al. (2020); as they treated the high tolerant wheat cultivar (Suntop) and the sensitive wheat cultivar (Sunmate) with $100 \mathrm{mM} \mathrm{NaCl}$. They found that the expression level of the NHX1 gene was upregulated in Suntop (tolerant cultivar) while downregulated in Sunmate (sensitive cultivar). Also, its reported a 28-fold increment in the expression of the TaNHX1 gene in the leaves of Cv. Kh65 (salt-tolerant), while it was about a 4-fold increase in Cv. HD2009 (sensitive) (Rana et al., 2016).

Besides, the SOS signaling pathway is verified to have a vital regulatory role in salt tolerance either directly or indirectly, through controlling $\mathrm{Na}^{+}$ion homeostasis and mitigate osmotic stress caused by extreme salt conditions (Hasegawa et al., 2000; Zhu, 2000). Among the SOS gene family, SOS1 (a trans-membrane $\mathrm{Na}^{+} / \mathrm{H}^{+}$antiporter) and SOS4 [a cytoplasmic pyridoxal (PL) kinase] genes were reported to play a critical regulatory role in salt tolerance. Our qRT-PCR results showed that the TaSOS1 and TaSOS4 genes generally recorded a significant up-regulation expressional levels between the salt-treated groups (priming, priming+shock and shock) compared to control. For TaSOS1, the expression levels exhibited significant differences among the salt-treated groups (priming, priming+shock and shock). Meanwhile, no significant differences were noted in the TaSOS4 gene between the salt-treated groups (priming, priming+shock and shock). These consistent expression levels might be because TaSOS4 is apparently involved in salt tolerance but has not been recognized as part of the SOS1, 2, and 3 pathways. Our results were in parallel with Liu et al. 
(2019) work, as they studied the expression level of TaSOS1 and TaSOS4. Their study found a significant difference in the expression level of the TaSOS1 gene compared to control, while for TaSOS4, there was no significant difference. Likewise, Ahmadi et al. (2020) proved that salinity stress increased the relative expression of the TaSOS1 gene in several ancestral and domesticated wheat genotypes.

High-affinity Potassium Transporters (HKTs) belong to an influential class of integral membrane proteins (IMPs) that promote cation transport across plant cells' plasma membranes. The HKT protein family is critical for salinity tolerance in commercially important crop species, particularly in wheat, by excluding $\mathrm{Na}^{+}$ ions from sensitive shoot tissues in plants. Among the high-affinity $\mathrm{K}$ transporters (HKTs) gene family, TaHKT1 and TaHKT2 are necessary transporters that display specificity for $\mathrm{K}^{+}$over $\mathrm{Na}^{+}$(Assaha et al., 2017; Kosová et al., 2013). Our results for the TaHKT1 and TaHKT2 genes expression levels revealed significantly raise values in the salt-pretreated group (priming+shock) compared to the non-pretreated group (shock only). In agreement with our results, Ahmadi et al. (2020) recorded a significant increase in the TaHKT1 expressional level by approximately 25 -fold under salinity stress.

On the other hand, Wheat $T a A K T 1$ functions as a potassium ion transporter, the inward rectifier $\mathrm{K}^{+}$ channel (AKT1) is considered an essential pathway for the uptake of $\mathrm{K}^{+}$in root cell (Wang and Wu, 2013). Our finding showed that the expression level of the TaAKT1 gene in the salt-pretreated group (priming+shock) was higher than the non-pretreated group (shock only). This finding was in complete agreement with Zeeshan et al. (2020), in which they found that the expression of the TaAKT1 gene was significantly upregulated under salinity stress in the tolerant wheat cultivar ('Suntop') while downregulated in the sensitive wheat cultivar ('Sunmate').

\section{Conclusions}

The salt-induced priming approach improved salt acclimation capacity in bread wheat by enhancing osmotic balancing and mitigating ionic toxicity. Noticeably, all results obtained in this study (agronomic, physiological, and gene expression) presented strong evidence for the positive effects of the long-term saltinduced priming approach to increase wheat productivity. Our findings indicated that exposing wheat plants to a smart salt-priming system enhances the survival possibility under saline conditions and this approach could be successfully applied in exploiting coastal saline land.

\section{Authors' Contributions}

Conceptualization, MAMA.; methodology, TKA and HA; software, MAMA; OA; TKA, HSE, and MAA; validation, TKA and HA; formal analysis, MAMA, OA, ME, MAA; investigation, MAMA, TKA and HA; resources, OA, MAA and MAMA; data curation, TK and MAMA.; writing-original draft preparation, TKA, HA, ME, HSE,OA, MAA and MAMA; writing-review and editing, MAMA; visualization, MAMA; TKA and OA; supervision, MAMA; project administration, MAMA and OA; funding acquisition, $\mathrm{OA}$ and MAMA. All authors read and approved the final manuscript.

\section{Acknowledgements}

This research was funded by the Deanship of Scientific Research (DSR), University of Tabuk, Saudi Arabia, for monetary support, under grant no. S-1440-0165.

Special thanks to the Deanship of Scientific Research (DSR), University of Tabuk, Saudi Arabia, for their support. The authors sincerely thank the Plant GenBank in the National Agriculture \& Animal Resources 
Research Center, Ministry of Environment Water \& Agriculture in Saudi Arabia, for providing the Saudi wheat samples used for experiments. Also, the authors would like to thank the administration of the Agricultural Genetic Engineering Research Institute (AGERI), as well as the administration of the Agricultural Research Center (ARC), Egypt, for their continued support.

\section{Conflict of Interests}

The authors declare that there are no conflicts of interest related to this article.

\section{References}

Abdelaziz ME, Abdelsattar M, Abdeldaym EA, Atia MA, Mahmoud AW, ... Hirt H (2019). Piriformospora indica alters $\mathrm{Na}+/ \mathrm{K}+$ homeostasis, antioxidant enzymes and LeNHX1 expression of greenhouse tomato grown under salt stress. Scientia Horticulturae 256:1-8. https://doi.org/10.1016/j.scienta.2019.05.059

Ahmadi J, Pour-Aboughadareh A, Ourang SF, Khalili P, Poczai P (2020). Unraveling salinity stress responses in ancestral and neglected wheat species at early growth stage: A baseline for utilization in future wheat improvement programs. Physiology and Molecular Biology of Plants 26:537-549. https://doi.org/10.1007/s12298-02000768 -4

Almansouri M, Kinet JM, Lutts S (1999). Compared effects of sudden and progressive impositions of salt stress in three durum wheat (Triticum durum Desf.) cultivars. Journal of Plant Physiology 154:743-752. https://doi.org/10.1016/S0176-1617(99)80253-3

Alshehri MA, Alzahrani O, Aziza AT, Alasmari A, Ibrahim S, ... Alduaydi SA (2020). Correlation and genetic analyses of different characteristics in Saudi Arabian wheat reveal correlation networks and several trait-associated markers. Journal of Animal and Plant Science 30:1486-1497. https://doi.org/10.36899/JAPS.2020.6.0169

Assaha DV, Ueda A, Saneoka H, Al-Yahyai R, Yaish MW (2017). The role of Na+ and K+ transporters in salt stress adaptation in glycophytes. Frontiers in Physiology 8:509-527. https://doi.org/10.3389/fphys.2017.00509

Atia MA, Abdeldaym EA, Abdelsattar M, Ibrahim DS, Saleh I, ... Abdelaziz ME (2020). Piriformospora indica promotes cucumber tolerance against Root-knot nematode by modulating photosynthesis and innate responsive genes. Saudi Journal of Biological Science 27:279-287. https://doi.org/10.1016/j.sjbs.2019.09.007

Barragán V, Leidi EO, Andrés Z, Rubio L, De Luca A, ... Pardo JM (2012). Ion exchangers NHX1 and NHX2 mediate active potassium uptake into vacuoles to regulate cell turgor and stomatal function in Arabidopsis. The Plant Cell 24(3):1127-1142. https://doi.org/10.1105/tpc.111.095273

Benderradji L, Brini F, Amar SB, Kellou K, Azaza J, ... Hanin M (2011). Sodium transport in the seedlings of two bread wheat (Triticum aestivum L.) genotypes showing contrasting salt stress tolerance. Australian Journal of Crop Science 5:233-241.

Bodirsky BL, Rolinski S, Biewald A, Weindl I, Popp A, Lotze-Campen H (2015). Global food demand scenarios for the 21 st century. PloS One 10(11):1-27. https://doi.org/10.1371/journal.pone.0139201

Brini F, Gaxiola RA, Berkowitz GA, Masmoudi K (2005). Cloning and characterization of a wheat vacuolar cation/proton antiporter and pyrophosphatase proton pump. Plant Physiology and Biochemistry 43:347-354. https://doi.org/10.1016/j.plaphy.2005.02.010.

Brini F, Hanin M, Mezghani I, Berkowitz GA, Masmoudi K (2007). Overexpression of wheat $\mathrm{Na}+/ \mathrm{H}+$ antiporter TNHX1 and H+-pyrophosphatase TVP1 improve salt-and drought-stress tolerance in Arabidopsis thaliana plants. Journal of Experimental Botany 58:301-308. https://doi.org/10.1093/jxb/erl251.

Chaves MM, Oliveira MM (2004). Mechanisms underlying plant resilience to water deficits: prospects for water-saving agriculture. Journal of Experimental Botany 55:2365-2384. https://doi.org/10.1093/jxb/erh269.

Chen Z, Pottosin II, Cuin TA, Fuglsang AT, Tester M, ... Shabala S (2007). Root plasma membrane transporters controlling $\mathrm{K}+/ \mathrm{Na}+$ homeostasis in salt-stressed barley. Plant Physiology 145:17141725. https://doi.org/10.1104/pp.107.110262 
Cuin TA, Bose J, Stefano G, Jha D, Tester M, Mancuso S, Shabala S (2011). Assessing the role of root plasma membrane and tonoplast $\mathrm{Na}+/ \mathrm{H}+$ exchangers in salinity tolerance in wheat: in planta quantification methods. Plant, Cell and Environment 34:947-961. https://doi.org/10.1111/j.1365-3040.2011.02296.x

Dawi F, El-Beltagi HS, Abdel-Mobdy YE, Salah SM, Ghaly IS, Abdel-Rahim EA, ... Soliman AM (2021). Synergistic impact of the pomegranate peels and its nanoparticles against the infection of tobacco mosaic virus (TMV). Fresenius Environmental Bulletin 30(1):731-746.

Djanaguiraman M, Boyle DL, Welti R, Jagadish SV, Prasad PV (2018). Decreased photosynthetic rate under high temperature in wheat is due to lipid desaturation, oxidation, acylation, and damage of organelles. BMC Plant Biology 18:1-17. https://doi.org/10.1186/s12870-018-1263-Z

Eissa HF, Hassanien SE, Ramadan AM, El-Shamy MM, Saleh OM, ... Hassan SM (2017). Developing transgenic wheat to encounter rusts and powdery mildew by overexpressing barley chi26 gene for fungal resistance. Plant Methods 13(1):41-53. https://doi.org/10.1186/s13007-017-0191-5

El-Beltagi HS, Mohamed HI, Sofy MR (2020a). Role of ascorbic acid, glutathione and proline applied as singly or in sequence combination in improving chickpea plant through physiological change and antioxidant defense under different levels of irrigation intervals. Molecules 25:1702; https://doi.org/10.3390/molecules25071702

El-Beltagi HS, Sofy MR, Aldaej MI, Mohamed HI (2020b). Silicon alleviates copper toxicity in flax plants by up-regulating antioxidant defense and secondary metabolites and decreasing oxidative damage. Sustainability 12:4732. http://doi.org/10.3390/su12114732

El-Hendawy S, Al-Suhaibani N, Elsayed S, Alotaibi M, Hassan W, Schmidhalter U (2019). Performance of optimized hyperspectral reflectance indices and partial least squares regression for estimating the chlorophyll fluorescence and grain yield of wheat grown in simulated saline field conditions. Plant Physiology and Biochemistry 144:300311. https://doi.org/10.1016/j.plaphy.2019.10.006

Elshafei AA, Afiah SA, Al-Doss AA, Ibrahim EI (2019). Morphological variability and genetic diversity of wheat genotypes grown on saline soil and identification of new promising molecular markers associated with salinity tolerance. Journal of Plant Interactions 14:564-571. https://doi.org/10.1080/17429145.2019.1672815

Farooq MA, Saqib ZA, Akhtar J (2015). Silicon-mediated oxidative stress tolerance and genetic variability in rice (Oryza sativa L.) grown under combined stress of salinity and boron toxicity. Turkish Journal of Agriculture and Forestry 39:718-729. http://journals.tubitak.gov.tr/agriculture/

Feki K, Quintero FJ, Pardo JM, Masmoudi K (2011). Regulation of durum wheat Na+/H+ exchanger TdSOS1 by phosphorylation. Plant Molecular Biology 76(6):545-556. https://doi.org/10.1007/s11103-011-9787-8

Filippou P, Tanou G, Molassiotis A, Fotopoulos V (2013). Plant acclimation to environmental stress using priming agents. In: Tuteja N, Singh Gill S (Eds). Plant Acclimation to Environmental Stress. Springer, New York pp 1-27.

Gálvez FJ, Baghour M, Hao G, Cagnac O, Rodríguez-Rosales MP, Venema K (2012). Expression of LeNHX isoforms in response to salt stress in salt sensitive and salt tolerant tomato species. Plant Physiology and Biochemistry 51:109-115. https://doi.org/10.1016/j.plaphy.2011.10.012

Gaxiola RA, Rao R, Sherman A, Grisafi P, Alper SL, Fink GR (1999). The Arabidopsis thaliana proton transporters, AtNhx1 and Avp1, can function in cation detoxification in yeast. PNAS 96(4):1480-1485. https://doi.org/10.1073/pnas.96.4.1480

Godfray HC, Beddington JR, Crute IR, Haddad L, Lawrence D, ... Toulmin C (2010). Food security: the challenge of feeding 9 billion people. Science 327:812-818. https://doi.org/10.1126/science.1185383

Gupta B, Huang B (2014). Mechanism of salinity tolerance in plants: physiological, biochemical, and molecular characterization. International Journal of Genomics 2014:263-280. https://doi.org/10.1155/2014/701596.

Hasegawa PM, Bressan RA, Zhu JK, Bohnert HJ (2000). Plant cellular and molecular responses to high salinity. Annual Review of Plant Physiology and Plant Molecular Biology 51(1):463-499. https://doi.org/10.1146/annurev.arplant.51.1.463

Hasson E, Poljakoff-Mayber A, Gale J (1983). The effect of salt species and concentration on photosynthesis and growth of pea plants (Pisum sativum L. cv. Alaska). In: Marcelle R, Clijsters H, van Poucke M (Eds). Effects of Stress on Photosynthesis. Springer, Dordrecht pp 305-311.

Heath RL, Packer L (1968). Photoperoxidation in isolated chloroplasts: I. Kinetics and stoichiometry of fatty acid peroxidation. Archives of Biochemistry and Biophysics 125(1):189-98. https://doi.org/10.1016/00039861(68)90654-1

Ishitani M, Liu J, Halfter U, Kim CS, Shi W, Zhu JK (2000). SOS3 function in plant salt tolerance requires Nmyristoylation and calcium binding. The Plant Cell 12(9):1667-1677. https://doi.org/10.1105/tpc.12.9.1667 
Jamil A, Riaz S, Ashraf M, Foolad MR (2011). Gene expression profiling of plants under salt stress. Critical Reviews in Plant Sciences 30(5):435-458. https://doi.org/10.1080/07352689.2011.605739.

Kanawapee N, Sanitchon J, Srihaban P, Theerakulpisut P (2013). Physiological changes during development of rice (Oryza sativa L.) varieties differing in salt tolerance under saline field condition. Plant and Soil 370(1-2):89-101. https://doi.org/10.1007/s11104-013-1620-5

Kosová K, Vítámvás P, Urban MO, Prášil IT (2013). Plant proteome responses to salinity stress-comparison of glycophytes and halophytes. Functional Plant Biology 40(9):775-786. https://doi.org/10.1071/FP12375

Kumar S, Beena AS, Awana M, Singh A (2017). Physiological, biochemical, epigenetic and molecular analyses of wheat (Triticum aestivum) genotypes with contrasting salt tolerance. Physiological, biochemical, epigenetic and molecular analyses of wheat (Triticum aestivum) genotypes with contrasting salt tolerance. Frontiers in Plant Science 8:1151-1570. https://doi.org/10.3389/fpls.2017.01151

Kumar S, Beena AS, Awana M, Singh A (2017). Salt-induced tissue-specific cytosine methylation downregulates expression of HKT genes in contrasting wheat (Triticum aestivum L.) genotypes. DNA Cell Biology 36(4):283294. https://doi.org/10.1089/dna.2016.3505

Liu J, Ishitani M, Halfter U, Kim CS, Zhu JK (2000). The Arabidopsis thaliana SOS2 gene encodes a protein kinase that is required for salt tolerance. Proceedings of the National Academy of Science 97:3730-3734. https://doi.org/10.1073/pnas.97.7.3730.

Liu T, Zhuang L, Huang B (2019). Metabolic adjustment and gene expression for root sodium transport and calcium signaling contribute to salt tolerance in Agrostis grass species. Plant and Soil 443(1-2):219-232. https://doi.org/10.1007/s11104-019-04140-8.

Majeed M, Khaneghah AM, Kadmi Y, Khan MU, Shariati MA (2018). Assessment of ochratoxin A in commercial corn and wheat products. Current Nutrition and Food Science 14(2):116-120. https://doi.org/10.2174/1573401313666170330155823

Mohammed AM, Diab MR, Abdelsattar M, Sayed MS (2017). Characterization and RNAi-mediated knockdown of Chitin Synthase A in the potato tuber moth, Phthorimaea operculella. Scientific Reports 7(1):1-12. https://doi.org/10.1038/s41598-017-09858-y

Mohamed HI, Akladious SA, El-Beltagi HS (2018). Mitigation the harmful effect of salt stress on physiological, biochemical and anatomical traits by foliar spray with trehalose on wheat cultivars. Fresenius Environmental Bulletin 27(10):7054-7065.

Mokhtar MM, Atia MA (2019). SSRome: an integrated database and pipelines for exploring microsatellites in all organisms. Nucleic Acids Research 47:244-252. https://doi.org/10.1093/nar/gky998

Oh DH, Lee SY, Bressan RA, Yun DJ, Bohnert HJ (2010). Intracellular consequences of SOS1 deficiency during salt stress. Journal of Experimental Botany 61(4):1205-1213. https://doi.org/10.1093/jxb/erp391

Paparella S, Araújo SS, Rossi G, Wijayasinghe M, Carbonera D, Balestrazzi A (2015). Seed priming: state of the art and new perspectives. Plant Cell Reports 34(8):1281-1293. https://doi.org/10.1007/s00299-015-1784-y

Parvaiz A, Satyawati S (2008). Salt stress and phyto-biochemical responses of plants-a review. Plant Soil and Environment 54:89-99. https://doi.org/10.17221/2774-PSE

Pervaiz Z, Afzal M, Xi S, Xiaoe Y, Ancheng L (2002). Physiological parameters of salt tolerance in wheat. Asian Journal of Plant Science 1:478-481. https://doi.org/10.3923/ajps.2002.478.481

Pitman MG, Läuchli A (2002). Global impact of salinity and agricultural ecosystems. In: Läuchli A, Lüttge U (Eds). Salinity: Environment-Plants-Molecules. Dordrecht, Netherlands pp 3-20.

Qados AM (2011). Effect of salt stress on plant growth and metabolism of bean plant Vicia faba (L.). Journal of Saudi Society of Agricultural Science 10(1):7-15. https://doi.org/10.1016/j.jssas.2010.06.002

Ramezani A, Niazi A, Abolimoghadam AA, Babgohari MZ, Deihimi T, ... Ebrahimie E (2013). Quantitative expression analysis of TaSOS1 and TaSOS4 genes in cultivated and wild wheat plants under salt stress. Molecular Biotechnology 53(2):189-197. https://doi.org/10.1007/s12033-012-9513-Z

Rana V, Ram S, Nehra K, Sharma I (2016). Expression of genes related to $\mathrm{Na}+$ exclusion and proline accumulation in tolerant and susceptible wheat genotypes under salt stress. Cereal Research Communications 44(3):404-413. https://doi.org/10.1556/0806.44.2016.009

Rao PS, Mishra B, Gupta SR (2013). Effects of soil salinity and alkalinity on grain quality of tolerant, semi-tolerant and sensitive rice genotypes. Rice Science 20(4):284-291. https://doi.org/10.1016/S1672-6308(13)60136-5 
Saade S, Maurer A, Shahid M, Oakey H, Schmöckel SM, ... Tester M (2016). Yield-related salinity tolerance traits identified in a nested association mapping (NAM) population of wild barley. Scientific Reports 6(1):1-9. https://doi.org/10.1038/srep32586

Sairam RK, Rao KV, Srivastava GC (2002). Differential response of wheat genotypes to long term salinity stress in relation to oxidative stress, antioxidant activity and osmolyte concentration. Plant Science 163(5):1037-1046. https://doi.org/10.1016/S0168-9452(02)00278-9

Salah SM, Yajing G, Dongdong C, Jie L, Aamir N, ... Jin H (2015). Seed priming with polyethylene glycol regulating the physiological and molecular mechanism in rice (Oryza sativa L.) under nano-ZnO stress. Scientific Reports 5:14278-14391. https://doi.org/10.1038/srep14278

Sani E, Herzyk P, Perrella G, Colot V, Amtmann A (2013). Hyperosmotic priming of Arabidopsis seedlings establishes a long-term somatic memory accompanied by specific changes of the epigenome. Genome Biology 14:59-81. https://doi.org/10.1186/gb-2013-14-6-r59

Sano N, Kim JS, Onda Y, Nomura T, Mochida K, ... Seo M (2017). RNA-Seq using bulked recombinant inbred line populations uncovers the importance of brassinosteroid for seed longevity after priming treatments. Scientific Reports 7:1-4. https://doi.org/10.1038/s41598-017-08116-5

Saqib M, Zörb C, Rengel Z, Schubert S (2005). The expression of the endogenous vacuolar $\mathrm{Na}+\mathrm{H}+$ antiporters in roots and shoots correlates positively with the salt resistance of wheat (Triticum aestivum L.). Plant Science 169(5):959-965. https://doi.org/10.1016/j.plantsci.2005.07.001

Schroeder JI, Delhaize E, Frommer WB, Guerinot ML, Harrison MJ, ... Tsay YF (2013). Using membrane transporters to improve crops for sustainable food production. Nature 497(7447):60-66. https://doi.org/10.1038/nature11909

Sestak Z, Catsky J, Jarvis PG (1971). Plant photosynthetic production: A manual of methods. In: Sestak Z, Catsky J, Jarvis PG, Junk NV (Eds). Phytochemistry. The Hague, England pp 3-20.

Shabala S, Cuin TA (2008). Potassium transport and plant salt tolerance. Physiologia Plantarum 33(4):651669. https://doi.org/10.1111/j.1399-3054.2007.01008.X

Shabnam N, Tripathi I, Sharmila P, Pardha-Saradhi P (2016). A rapid, ideal, and eco-friendlier protocol for quantifying proline. Protoplasma 253(6):1577-1582. https://doi.org/10.1007/s00709-015-0910-6

Shao T, Li L, Wu Y, Chen M, Long X, Shao H, Liu Z, Rengel Z (2016). Balance between salt stress and endogenous hormones influence dry matter accumulation in Jerusalem artichoke. Science of the Total Environment 568:891-898. https://doi.org/10.1016/j.scitotenv.2016.06.076

Shavrukov, Y (2013). Salt stress or salt shock: which genes are we studying? Journal of Experimental Botany 64:119-127. https://doi.org/10.1093/jxb/ers316

Shi H, Ishitani M, Kim C, Zhu JK (2000). The Arabidopsis thaliana salt tolerance gene SOS1 encodes a putative $\mathrm{Na}+/ \mathrm{H}+$ antiporter. PNAS 97(12):6896-6901.https://doi.org/10.1073/pnas.120170197

Shiferaw B, Prasanna BM, Hellin J, Bänziger M (2011). Crops that feed the world 6. Past successes and future challenges to the role played by maize in global food security. Food Security 3(3):307-327. https://doi.org/10.1007/s12571-011-0140-5

Shoresh M, Spivak M, Bernstein N (2011). Involvement of calcium-mediated effects on ROS metabolism in the regulation of growth improvement under salinity. Free Radical Biology and Medicine 51(6):1221-1234. https://doi.org/10.1016/j.freeradbiomed.2011.03.036

Soda N, Sharan A, Gupta BK, Singla-Pareek SL, Pareek A (2016). Evidence for nuclear interaction of a cytoskeleton protein (OsIFL) with metallothionein and its role in salinity stress tolerance. Scientific Reports 6:1-14. https://doi.org/10.1038/srep34762

Tari AF (2016). The effects of different deficit irrigation strategies on yield, quality, and water-use efficiencies of wheat under semi-arid conditions. Agricultural Water Management 167:1-10. https://doi.org/10.1016/j.agwat.2015.12.023

Varier A, Vari AK, Dadlani M (2010). The subcellular basis of seed priming. Current Science 25:450-456. https://www.jstor.org/stable/24109568

Wang Y, Wu WH (2013). Potassium transport and signaling in higher plants. Annual Review of Plant Biology 64:451476. https://doi.org/10.1146/annurev-arplant-050312-120153

Xu Y, Zhou Y, Hong S, Xia Z, Cui D, ... Jiang X (2013). Functional characterization of a wheat NHX antiporter gene TaNHX2 that encodes a $\mathrm{K}+/ \mathrm{H}+$ exchanger. PLoS One 8:1-12. https://doi.org/10.1371/journal.pone.0078098 
Yan M (2015). Seed priming stimulate germination and early seedling growth of Chinese cabbage under drought stress South African Journal of Botany 99:88-92. https://doi.org/10.1016/j.sajb.2015.03.195

Zeeshan M, Lu M, Naz S, Sehar S, Cao F, Wu F (2020). Resemblance and difference of seedling metabolic and transporter gene expression in high tolerance wheat and barley cultivars in response to salinity stress. Plants 9:519-535. https://doi.org/10.3390/plants9040519

Zhang T, Zhan X, Kang Y, Wan S, Feng H (2017). Improvements of soil salt characteristics and nutrient status in an impermeable saline-sodic soil reclaimed with an improved drip irrigation while ridge planting Lycium barbarum L. Journal of Soils and Sediments 17(4):1126-1139. https://doi.org/10.1007/s11368-016-1600-5

Zhao C, Zhang H, Song C, Zhu JK, Shabala S (2020). Mechanisms of plant responses and adaptation to soil salinity. The Innovation 21:1-41. https://doi.org/10.1016/j.xinn.2020.100017

Zhao Y, Li Y, Wang J, Pang H, Li Y (2016). Buried straw layer plus plastic mulching reduces soil salinity and increases sunflower yield in saline soils. Soil and Tillage Research 155:363-370. https://doi.org/10.1016/j.still.2015.08.019

Zhu JK (2000). Genetic analysis of plant salt tolerance using Arabidopsis. Plant Physiology 124(3):941-948. https://doi.org/10.1104/pp.124.3.941

Zhu JK (2003). Regulation of ion homeostasis under salt stress. Current Opinion in Plant Biology 6(5):441-445. https://doi.org/10.1016/s1369-5266(03)00085-2

Zou P, Li K, Liu S, He X, Zhang X, Xing R, Li P (2016). Effect of sulfated chitooligosaccharides on wheat seedlings (Triticum aestivum L.) under salt stress. Journal of Agricultural and Food Chemistry 64(14):2815-2821. https://doi.org/10.1021/acs.jafc.5b05624
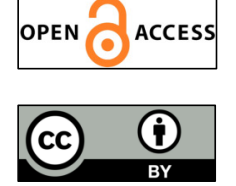

The journal offers free, immediate, and unrestricted access to peer-reviewed research and scholarly work. Users are allowed to read, download, copy, distribute, print, search, or link to the full texts of the articles, or use them for any other lawful purpose, without asking prior permission from the publisher or the author.

License - Articles published in Notulae Botanicae Horti Agrobotanici Cluj-Napoca are Open-Access, distributed under the terms and conditions of the Creative Commons Attribution (CC BY 4.0) License.

(c) Articles by the authors; UASVM, Cluj-Napoca, Romania. The journal allows the author(s) to hold the copyright/to retain publishing rights without restriction. 